\title{
Corporal and testicular biometry in wild boar from birth to 12 months of age
}

\author{
Danillo Velloso Ferreira Murta ${ }^{1}$, Deiler Sampaio Costa², Marcelo Diniz Santos ${ }^{3}$, \\ Fábio José Carvalho Faria ${ }^{2}$, Tarcízio Antônio Rêgo de Paula
}

\begin{abstract}
The aim of this tudy was to evaluate corporal and testicular development in wild boars (Sus scrofa scrofa) from birth to 12 months of age, evaluating body weight, biometric testicular parameters, and gonadosomatic index. Thirty-nine male wild boars from a commercial farm licensed by IBAMA were used in the study. The animals were weighed and assigned to 13 experimental groups. The testes were recovered through unilateral orchiectomy, weighed on an analytical balance and measured for length, width and thickness. Body weight and testicular measures increased with the age, up to 12 months, and were more accelerated in the first and ninth months. Initially the testicular growth pattern, between zero and nine months, followed the body growth, and the gonadosomatic index varied from 0.07 to $0.09 \%$. Between 9 and 11 months, the testicular growth was superior to the body growth, and the gonadosomatic index varied from 0.09 to $0.16 \%$. Finally, after 11 months of age, testicular and body growth had a similar behavior. In conclusion, body weight, testicular biometry, and gonadosomatic index development accelerated in the ninth month.
\end{abstract}

Key words: body weight, gonadosomatic index, testicular development, Sus scrofa scrofa.

\section{RESUMO}

\section{Biometria corporal e testicular de javalis do nascimento aos 12 meses de idade}

Objetivou-se, com esta pesquisa, investigar o desenvolvimento testicular e corporal de javalis (Sus scrofa scrofa), do nascimento aos 12 meses de idade, avaliando-se, em cada faixa etária, o peso corporal, o desenvolvimento biométrico dos testículos e o índice gonadossomático (IGS). Utilizaram-se 52 javalis machos, provenientes de um criatório comercial, devidamente regulamentado pelo IBAMA. Os animais foram pesados e divididos em 13 grupos experimentais; os testículos foram coletados por orquiectomia unilateral e, em seguida, pesados em balança analítica e mensurados comprimento, largura e espessura. Os valores de peso corporal e as medidas testiculares foram crescentes, após o nascimento, sendo sua variação mais acelerada no primeiro mês e aos nove meses. Inicialmente, o padrão de crescimento testicular, do nascimento aos nove meses de idade, acompanhou o crescimento corporal e o índice gonadossomático variou de 0,07 a 0,09\%. Em seguida, entre nove e 11 meses, o valor de crescimento testicular foi superior ao de crescimento corporal e o índice gonadossomático variou de 0,09 a 0,16\%. Por fim, após os 11 meses de idade, os valores crescimento corporal e dos testículos voltaram a se comportar de forma semelhante. Conclui-se que o desenvolvimento do peso corporal, a biometria testicular e o IGS tiveram crescimento mais acelerado aos nove meses de idade.

Palavras-chave: peso corporal, índice gonadossomático, desenvolvimento testicular, Sus scrofa scrofa.

Received: 17/07/2009; Accepted: 27/12/2012.

${ }^{1}$ Veterinarian surgeon, Doctoral student. Faculdade de Medicina Veterinária e Zootecnia, Universidade Federal de Mato Grosso do Sul (UFMS), Caixa Postal 549, 79070-900, Campo Grande, Mato Grosso do Sul, Brasil. danillo.murta.vet@gmail.com

2 Veterinarian surgeon, Doctor of Science. Faculdade de Medicina Veterinária e Zootecnia, Universidade Federal de Mato Grosso do Sul (UFMS), Caixa Postal 549, 79070-900, Campo Grande, Mato Grosso do Sul, Brasil. deilercosta@yahoo.com.br (corresponding author); fariafjc@nin.ufms.br

${ }^{3}$ Veterinarian surgeon, Doctor of Science. Faculdade de Medicina Veterinária, Universidade de Cuiabá, Cuiabá, Mato Grosso, Brasil. dinizms@uol.com.br

${ }^{4}$ Veterinarian surgeon, Doctor of Science. Departamento de Veterinária, Universidade Federal de Viçosa, Campus Viçosa, Avenida Peter Henry Rolfs, s/n, 36570-000, Viçosa, Minas Gerais, Brasil. tarcizio@ufv.br 


\section{INTRODUCTION}

Raising wild boars (Sus scrofa), collared peccaries (Tayassu tajacu) and white-lipped peccaries (Tayassu pecari) for commercial farming, besides being very profitable, can stop the illegal trade of meat, skin and other products (Costa \& Silva, 2006). Despite the increasing demand and the productive potential of these species, few studies have been found in the literature about the basics of reproductive physiology and management of these animals. It is known that in both programs of preservation and livestock improvement of any species or breed rely on the basic knowledge about reproductive aspects.

The evolution of the various stages of testis development, especially those associated with puberty and sexual maturity, are critical for determining when a young boar can first be used for service. Therefore, testicular dimensions are important parameters in andrological evaluation and provide information that allows assessment of the normality of these organs and the ability of sperm production (Amann, 1970; France \& Russell, 1998).

The testicular development generally follows the same pattern in several mammalian species and is highly correlated with body weight and age. In the first months after birth, the testes exhibit slow growth, due to the initial period of cell proliferation, followed by a period of more accelerated growth, near the puberty, until sexual maturity, when it takes a more gradual growth, mainly related with the increase in connective tissue in the organs (Thomas \& Raja, 1980; Schinckel et al. 1983). This accelerated growth during the pubescent and post-pubescent periods is related to the volume increase of Sertoli cells and germ cell mitotic divisions in the seminiferous tubules, resulting in the appearance of primary spermatocytes from spermatogonia. Thus, there is an increase in the tubular diameter and also the scrotal circumference (Assis Neto et al., 2003).

Although the spermatogenesis in adult wild boars is well characterized (Almeida et al., 2006; Costa \& Silva, 2006), there are no reports describing the testicular development from birth, and such knowledge can foster production, management and enhancement of reproductive efficiency, thereby reducing the cost of maintenance on farms.

The aim of this study is, therefore, to investigate the testicular and body development of wild boar, from birth to 12 months of age, evaluating in each age group the body weight, biometric development of testicles and gonadosomatic index (GSI).

\section{MATERIAL AND METHODS}

Fifty-two male wild boars, from the breeding farm "Yacan do Alto Agronegócios Ltda", properly licensed by IBAMA (License for collection 02022.008582/2004-81), in the municipality of Nova Friburgo - RJ were used. The animals were reared in intensive system and fed elephant grass, leftover fruits and vegetables, corn and soybean meal. The piglets were kept in nursing system, during the first 60 days of life.

Thirteen experimental groups were formed, with ages from zero to 12 months. The boars were weighed according to each experimental group, as they reached the group age. Subsequently, the boars were sedated with $1.0 \mathrm{~mL} /$ $20 \mathrm{~kg}$ IM Suicalm ${ }^{\circledR}$ (Azaperone) associated with $10.0 \mathrm{mg}$ IM of Diazepam ${ }^{\circledR}$ (Diazepam) and unilateral castration was performed according to routine technique. Immediately after surgery, epididymis was separated from their testis and length, width and thickness were measured using a caliper divided in millimeters.

The testis gross weight (g) was obtained, using a precision scale, referring only to one testicle. The gonadosomatic index, which expresses the relationship between testicular mass and total body weight, was calculated by dividing the gross weight of the testicle (multiplied by two) by body weight and the result was multiplied by one hundred (Costa et al., 2004).

The testis net weight ( $\mathrm{g}$ ) was estimated by subtracting the weight of the tunica albuginea from the testis gross weight. The mediastinum weight was not taken because of the methodological problems in standardizing the removal technique, because of the different sizes of the testes in the different age groups.

All procedures reported in this study were approved by the Ethics Committee on Animal Research/CEUA of the Federal University of Mato Grosso do Sul, Protocol 134/2006.

Data were presented as means and standard deviations and Pearson correlation analyses were performed with 5\% probability of error. Regression equations were estimated for body weight and testis gross weight, to determine the development rate of both parameters in relation to age.

\section{RESULTS}

Table 1 shows the values for body weight (BW), testicular weight, gonadosomatic index (GSI), albuginea weight (AW) and the percentage of the testis occupied by albuginea in wild boars from birth to 12 months of age.

The development of body weight showed significant relationship with age $(r=0.99)$ and showed more intense increase during the first month of life, and more gradually up to nine months. Between nine and ten months, there was again a more intense growth and then it became more gradual until 12 months of age.

The increase in gross testicular weight showed high correlations with age $(r=0.90)$ and body weight $(r=0.90)$, with the development curve with rapid evolution in the 
first month of life and from nine months of age. The GSI, from birth to nine months, ranged from 0.07 to $0.09 \%$, and between nine and 12 months, evolved from 0.09 to $0.16 \%$. This index showed significant correlations with age $(\mathrm{r}=$ $0.68)$, body weight $(\mathrm{r}=0.70)$ and gross testicular weight $(\mathrm{r}$ $=0.85)$. The equations estimated from the regression of body weight and from the gross testicular weight were as follows: $\mathrm{y} 1=1.672+1.396 \mathrm{x}$ and $\mathrm{y}=-1.233+1.053 \mathrm{x}$, respectively (where $\mathrm{y}=$ body weight and $\mathrm{x}=$ gross testicular weight).

The albuginea weight showed the growth curve similar to that of the testicular weight, but at a slower rate, and the percentage of the testis occupied by albuginea decreased from birth.

Table 2 shows that the volume, length, width and thickness of testes from wild boars raised in captivity, from birth to 12 months of age, developed in a similar way to the body and testicular weights, more accelerated from nine months of age.

\section{DISCUSSION}

The body weight of wild boars raised in captivity, in the various age groups, was lower than that described for domestic pigs (Godinho et al., 1979; Thomas \& Raja, 1980). The rate of body weight gain of wild boars increased with age, with periods of greater acceleration. The first period of greatest weight gain occurred after birth, in the first month of life, during the lactation stage. The second phase of accelerated body growth was between nine and ten months, coinciding with puberty. These growth peaks are also seen in most species studied (França et al., 2000; Assis Neto et al., 2003), except for horses, whose growth curve shows no peak period (Jones, 1998 ).
At 12 months, the body weight approached that reported for adult wild boars (Costa \& Silva, 2006), however, lower than that described by Almeida et al. (2006), also for this subspecies, which can be related to variations in the genetic profile of the animals, management and feeding, in each rearing facility.

The testicular weight varies among species and is determined by several factors, such as the establishment of the spermatogenic activity, increase in the population of germ cells and the number of Sertoli cells, showing direct effect on daily sperm production (Ferreira et al., 2004). The high correlation observed in this study between changes in testicular weight with age and body weight was similar to that described for domestic pigs (França et al. 1988; Thomas \& Raja, 1980) and other mammalian

Table 2. Testicular length, width and thickness of wild boars from birth to 12 months of age

\begin{tabular}{lcccc}
\hline $\begin{array}{l}\text { Age } \\
\text { (months) }\end{array}$ & $\mathbf{n}$ & $\begin{array}{c}\text { Length } \\
(\mathbf{c m})\end{array}$ & $\begin{array}{c}\text { Width } \\
(\mathbf{c m})\end{array}$ & $\begin{array}{c}\text { Thickness } \\
(\mathbf{c m})\end{array}$ \\
\hline 0 & 4 & $1.2 \pm 0.10$ & $0.9 \pm 0.06$ & $0.9 \pm 0.04$ \\
1 & 4 & $1.9 \pm 0.26$ & $1.2 \pm 0.12$ & $1.2 \pm .015$ \\
2 & 4 & $2.0 \pm 0.48$ & $1.3 \pm 0.07$ & $1.1 \pm 0.17$ \\
3 & 4 & $2.2 \pm 0.06$ & $1.2 \pm 0.06$ & $1.2 \pm 0.17$ \\
4 & 4 & $2.3 \pm 0.21$ & $1.4 \pm 0.11$ & $1.3 \pm 0.12$ \\
5 & 4 & $2.2 \pm 0.15$ & $1.3 \pm 0.12$ & $1.2 \pm 0.05$ \\
6 & 4 & $2.6 \pm 0.20$ & $1.4 \pm 0.11$ & $1.3 \pm 0.06$ \\
7 & 4 & $2.9 \pm 0.20$ & $1.6 \pm 0.06$ & $1.5 \pm 0.16$ \\
8 & 4 & $3.2 \pm 0.10$ & $1.9 \pm 0.28$ & $1.6 \pm 0.56$ \\
9 & 4 & $3.1 \pm 0.21$ & $2.0 \pm 0.15$ & $1.6 \pm 0.32$ \\
10 & 4 & $3.9 \pm 0.60$ & $2.7 \pm 0.80$ & $2.1 \pm 0.70$ \\
11 & 4 & $4.4 \pm 1.10$ & $3.1 \pm 0.43$ & $2.2 \pm 0.59$ \\
12 & 4 & $4.8 \pm 1.02$ & $3.4 \pm 0.97$ & $2.6 \pm 0.76$ \\
\hline
\end{tabular}

Table 1. Body weight, gross testicular weight, net testicular weight, gonadosomatic index (GSI), albuginea weight and percentage of the testis occupied by albuginea in wild boars from birth to 12 months of age

\begin{tabular}{lrrrrrrr}
\hline Age (months) & $\mathbf{n}$ & BW $(\mathbf{K g})$ & \multicolumn{1}{c}{ GTW $(\mathbf{g})^{*}$} & \multicolumn{1}{c}{ NTW $(\mathbf{g}) *$} & IGS $(\%)$ & AW $(\mathbf{g})$ & \% ALBUG \\
\hline 0 & 4 & $0.4 \pm 0.1$ & $0.14 \pm 0.08$ & $0.09 \pm 0.02$ & 0.07 & $0.05 \pm 0.01$ & $35.71 \pm 0.07$ \\
1 & 4 & $4.3 \pm 0.8$ & $1.92 \pm 0.26$ & $1.63 \pm 0.14$ & 0.09 & $0.29 \pm 0.12$ & $15.10 \pm 0.13$ \\
2 & 4 & $4.3 \pm 1.5$ & $2.25 \pm 0.89$ & $1.92 \pm 0.66$ & 0.10 & $0.33 \pm 0.11$ & $14.67 \pm 0.71$ \\
3 & 4 & $6.3 \pm 1.5$ & $2.46 \pm 0.94$ & $2.07 \pm 0.86$ & 0.08 & $0.39 \pm 0.14$ & $15.85 \pm 0.82$ \\
4 & 4 & $6.5 \pm 2.6$ & $2.51 \pm 0.37$ & $2.10 \pm 0.22$ & 0.08 & $0.41 \pm 0.17$ & $16.33 \pm 0.18$ \\
5 & 4 & $8.3 \pm 0.8$ & $2.70 \pm 0.55$ & $2.29 \pm 0.38$ & 0.06 & $0.41 \pm 0.15$ & $15.19 \pm 0.49$ \\
6 & 4 & $9.3 \pm 2.3$ & $3.26 \pm 0.60$ & $2.83 \pm 0.42$ & 0.07 & $0.43 \pm 0.11$ & $13.19 \pm 0.47$ \\
7 & 4 & $12.3 \pm 1.5$ & $3.94 \pm 1.13$ & $3.43 \pm 0.79$ & 0.06 & $0.51 \pm 0.09$ & $12.94 \pm 0.98$ \\
8 & 4 & $12.7 \pm 2.3$ & $4.85 \pm 0.72$ & $4.19 \pm 0.76$ & 0.08 & $0.66 \pm 0.16$ & $13.61 \pm 0.88$ \\
9 & 4 & $13.0 \pm 2.9$ & $5.87 \pm 1.32$ & $5.12 \pm 0.99$ & 0.09 & $0.75 \pm 0.16$ & $12.78 \pm 1.06$ \\
10 & 4 & $17.0 \pm 2.6$ & $8.92 \pm 1.94$ & $7.98 \pm 1.53$ & 0.10 & $0.94 \pm 0.11$ & $10.54 \pm 1.81$ \\
11 & 4 & $17.3 \pm 1.2$ & $13.54 \pm 1.45$ & $12.42 \pm 1.25$ & 0.16 & $1.12 \pm 0.21$ & $8.27 \pm 1.33$ \\
12 & 4 & $18.0 \pm 2.4$ & $14.08 \pm 1.70$ & $12.71 \pm 1.44$ & 0.16 & $1.37 \pm 0.28$ & $9.73 \pm 1.57$ \\
\hline
\end{tabular}

* Weight of only one testis

n - Number of animals per group; BW - Body weight (kg); GTW - Gross testicular weight (g); NTW - Net testicular weight (g); GSI Gonadosomatic index (\%); AW - albuginea weight (g); \% ALBUG - Percentage of the testis occupied by albuginea (\%). 
species (Johnson et al. 1991; Assis Neto et al. 2003; Ferreira et al. 2004).

The accelerated development of testicular weight in the first month, similar to the evolution of body weight was probably due to lactation, as observed in domestic pigs (França et al., 1988). The evolution of testicular weight, more intense around nine months, may be related to the establishment of puberty, as described for other mammals (Assis Neto et al. 2003; Ferreira et al. 2004). At this stage, associated with the increase in testicular weight, there is a higher cell proliferation in the seminiferous epithelium, establishment of full spermatogenesis and observation of spermatozoa in the tubular lumen. There is also differentiation and increase in volume of Sertoli cells, expansion of the tubular lumen and expansion of the diameter, length and volume of seminiferous tubules (França et al., 2000; Assis Neto et al., 2003). Thus, testicular development is an important parameter for the chronological development of spermatogenesis and establishment of puberty (Johnson et al. 1991).

The testicular weight observed at 12 months was lower than that described for sexually mature wild boars (Costa \& Silva, 2006; Almeida et al., 2006) and adult domestic pigs (Godinho et al., 1979; Thomas \& Raja, 1980; França et al . 1988; França et al. 2000). According to Berndtson et al. (1987), differences of up to $50 \%$ are common between individuals of the same species at similar ages. However, the development of testicular weight, as well as the body weight, lower in wild boars than in domestic pigs may be attributed to management and feeding of each rearing facility, environmental effects, as well as the procedures of selection and breeding, more intense in these domesticated animals (Schinckel et al., 1983).

According to the estimated regression equations, the body weight of wild boars increased approximately 1.396 $\mathrm{kg}$ and the gross weight of the testicle had estimated increase of $1.053 \mathrm{~g}$ per month. These results could not be compared with those of other studies, for lack of information in the literature.

The GSI expresses the relationship between total testicular mass and body weight, representing the percentage of body mass allocated in the testicles. This proportion varies among species and several theories seek to explain why some species allocate a higher percentage of body mass in the testis than others. The most accepted explanation in the scientific community, and that relates to most species, is based on the reproductive behavior and the number of females that each male serves (Kenagy \& Trombulack, 1986). Thus, in monogamous or extremely polygynous mammalian species, in which one male mates with all the females, there are breeding males with exclusive mating rights. These dominant males have smaller testes and GSIs compared with those individuals of species whose males do not have exclusive mating rights and the females mate with several males during the fertile period of the estrous cycle (polyandry). This difference can be explained by the selection pressure, related to sperm production, by the competition for fertilization inside the female genital tract, to ensure a greater number of offspring. Thus, species with higher sperm competition in the female genital tract require greater sperm production and hence larger testes (Short, 1997).

Other characteristics, such as the type of ovulation or duration of estrous in the females, also influence the testicular weight of breeding males and hence the GSI. In the case of polyandrous species, in which the females have spontaneous ovulation or more prolonged estrous, there is greater sperm competition and generally males of such species have heavier testes and higher GSI than those species whose ovulation is induced or show shorter heat periods (Kenagy \& Trombulack, 1986).

The testicular growth in relation to body development, in this study, showed three distinct evolution patterns. The first was recorded between birth and nine months of age, when the testicular growth followed the body growth and the GSI ranged from 0.07 to $0.09 \%$. The second was recorded between nine and 11 months of age, when the testicular growth was much greater than the body growth and the GSI of these animals was in the range of 0.09 to $0.16 \%$. The last evolution pattern occurred after 11 months of age, when the testicular and body growth again behave similarly. In the period in which the testicular development data were superior to those of body development, there was an abrupt rise of the GSI, confirming the significant correlation between these variables.

At 12 months of age, the GSI was $0.16 \%$, which was close to that reported in cathetus (Costa et al. 2004) and capybaras (Paula et al. 2002). However, it was approximately half of that described for adult wild boars (Almeida et al., 2006) and domestic pigs (Godinho et al. 1979; França et al. 2000). Although swines, both domestic and wild have similar sexual behavior, with a high copulatory frequency, it is likely that the low GSI in wild boars in this study is related to the lower testicular development in relation to the body weight, deriving from the absence of a selection program giving preference to animals of larger testes.

The weight of the testicular parenchyma is obtained by subtracting the weights of the albuginea and the mediastinum from the testis gross weight (Johnson et al., 1981). In most domestic species, the volumetric ratio of the albuginea and mediastinum is around 10\% (França \& Russell, 1998), which is close to the $9.4 \%$ reported for adult wild boars (Costa \& Silva, 2006). Given the methodological difficulties mentioned above, the weight of the mediastinum was not taken. The percentage 
occupied by the mediastinum in the testes of mammals is relatively low: $0.69 \%$ was reported for feral pigs (Costa et al., 2005) and $2.9 \%$ in collared peccaries (Costa et al., 2007), indicating that this value is little significant compared with the gross testicular weight.

The albuginea weight increased gradually from zero to 12 months, but slower than the testicular weight, therefore the percentage of the testis occupied by albuginea decreased after birth, probably because of the greater development of the tubular tissue. At 12 months, the proportion of the testis occupied by albuginea resembles that described for sexually mature wild boars (Costa \& Silva, 2006) and peccaries (Costa et al, 2007), however, is double that found in domestic pigs at corresponding age (França et al., 1988).

The testicular length and width are parameters that vary widely between species and with the evolution of age. The evaluation of these testicular measures is important for the selection of breeding males because it can provide reliable indications of the reproductive performance of the animal (Yarney \& Sanford, 1993). Therefore, the testicular width has a great relationship with testicular weight, volume and length and can be used as an indicator for other testicular biometric characteristics (Martins, 2006). The testicular volume, related to the testis weight, is an important variable to assess the ability of sperm production (Amann, 1970).

In wild boars, from birth to 12 months, the volume and other testicular biometric parameters (length, width and thickness) followed an upward trend similar to that observed for body and testicular weights, which had more intense evolution around nine months of age. This more intense increase was coincident with the establishment of puberty, as described for other mammals (França, 1988; Assis Neto et al. 2003).

\section{CONCLUSIONS}

The increase in body weight of male wild boars, as well as the testicular biometric parameters and the GSI exhibit a faster growth at nine months of age.

\section{REFERENCES}

Almeida FFL, Leal MC \& França LR (2006) Testis Morphometry, Duration of Spermatogenesis, and Spermatogenic Efficiency in the Wild Boar (Sus scrofa scrofa). Biology of Reproduction, 75:792-799.

Amann RP (1970) Sperm Production Rates. In. Johnson AD; Gomes WR \& Van Demark NL (Eds.) The Testis. New York, Academic Press. p.433-482.

Assis Neto AC Carvalho MAM, Melo MIV, Miglino MA, Oliveira M, Almeida MM, Papa PC \& Kfoury Júnior JR (2003) Aspectos biométricos do desenvolvimento testicular e corporal em cutias (Dasyprocta aguti) criadas em cativeiros. Brazilian Journal of Veterinary Research and Animal Science, 40:154-160.
Berndtson WE, Igboeli G \& Pickett BW (1987) Relationship of Absolute Numbers of Sertoli Cells to Testicular Size and Spermatogenesis in Young Beef Bulls. Journal Animal Science, 64:241-246.

Costa DS, Henry M \& Paula TAR (2004) Espermatogênese de Catetos (Tayassu tajacu). Arquivo Brasileiro de Medicina Veterinária e Zootecnia, 56:46-51.

Costa DS, Paes RCS, Costa Neto AA, Oliveira JM, Monteiro LARC, Ribeiro OC \& Henriques LSV (2005) Peso e percentual da túnica albugínea e mediastino testicular em porcos monteiro (Sus scrofa). In: $10^{\circ}$. Encontro de Iniciação Científica da UENF, Campos dos Goytacazes. Anais, UENF. CD-ROM.

Costa DS \& Silva JFS (2006) Wild boar (Sus scrofa scrofa) seminiferous tubules morphometry. Brazilian Archives of Biology and Technology, 49:739-745.

Costa DS, Menezes CMC \& Paula TAR (2007) Spermatogenesis in white-lipped peccaries (Tayassu pecari). Animal Reproduction Science, 98:322-334.

Ferreira ACS, Guimarães DAA, Luz-Ramos RS, Souza PC, Batista CR \& Ohashi OM (2004) Reproductive developmental of male agouti (Dasyprocta $s p$ ) raised in captivity determined by quantitative analysis of spermatogenic cells. Revista Brasileira de Reprodução Animal, 28:196-201.

França LR, Cardoso FM, Castro ACS \& Barbosa AS (1988) Desenvolvimento testicular de suínos Piau. I. Aspectos biométricos. Arquivo Brasileiro de Medicina Veterinária e Zootecnia, 40:165180 .

França LR \& Russell LD (1998) The testis of domestic animals. In: Regadera J. \& Martinez- Garcia F. (Eds.). Male reproduction. A multidisciplinary overview. Madrid, Churchill Livingstone. p.197-219.

França LR, Silva JR VA, Garcia HC, Garcia SK \& Debeljuk L (2000) Cell Proliferation and Hormonal Changes During Postnatal Development of the Testis in the Pig. Biology of Reproduction, 63:1629-1636.

Godinho HP, Cardoso FM \&Nogueira JC (1979) Desenvolvimento sexual de porcos yorkshire. I Crescimento dos órgãos genitais masculinos, do nascimento aos 15 meses de idade. Arquivo Brasileiro de Medicina Veterinária e Zootecnia, 31:343-350.

Johnson LV, Petty CS \& Neaves WB (1981) A new approach to qualification of spermatogenesis and its application to germinal cell attrition during human spermiogenesis. Biology of Reproduction, 25:217-226.

Johnson L, Varner DD \& Thompson Jr, DL (1991) Effect of age and season on the establishment of spermatogenesis in the horse. Journal of Reproduction and Fertility, 44:87-97.

Jones DN (1998) Desenvolvimento testicular de eqüinos mestiços da raça brasileira de hipismo, de 1 a 30 meses de idade. Dissertação de Mestrado. Escola de Veterinária, Universidade Federal de Minas Gerais, Belo Horizonte. 89p.

Kenagy GJ \& Trombulak SC (1986) Size and function of mammalian testes in relation to body size. Journal of Mammalogy, 67:1-22.

Martins JAM (2006) Avaliação da biometria testicular, epididimal e das glândulas sexuais acessórias e correlações entre características biométricas e histológicas em carneiros deslanados sem padrão racial definido (sprd). Dissertação de Mestrado. Universidade Federal do Ceará, Fortaleza. 56p.

Paula TAR, Costa DS \& Matta SLP (2002) Avaliação histológica quantitativa do testículo de capivaras (Hydrochoerus hydrochaers) adultas. Bioscience Journal, 18:121-136.

Rev. Ceres, Viçosa, v. 60, n.1, p. 001-006, jan/fev, 2013 
Schinckel A, Johnson RK, Pumfrey RJ \& Zimmerman DR (1983) Testicular growth in boars of different genetic lines and its relationship to reproductive performance. Journal Animal Science, 56:1065-76.

Short RV (1997) The testis: the witness of the mating system, the site of mutation and the engine of desire. Acta Paediatrics, 422:3-7.
Thomas UP \& Raja CKSV (1980) Postnatal development of testis and epididymis of Large White Yorkshire boars. Journal Veterinary Science, 2:277-86.

Yarney TA \& Sanford LM (1993) Pubertal development of ram lambs: physical and endocrinological traits in combination as indices of post pubertal reproductive function. Theriogenology, 40:735-744. 